\title{
Time-courses in the retention of food material in the bivalves Potamocorbula amurensis and Macoma balthica: significance to the absorption of carbon and chromium
}

\author{
Alan W. Decho, Samuel N. Luoma \\ US Geological Survey, MS 465, 345 Middlefield Rd., Menlo Park, California 94025, USA
}

\begin{abstract}
Time courses for ingestion, retention and release via feces of microbial food was investigated using 2 bivalves with different feeding strategies, Potamocorbula amurensis and Macoma balthica. The results showed 2 pathways for the uptake of food material in these clams. The first is represented by an initial label pulse in the feces. The second pathway operates over longer time periods. Inert ${ }^{51} \mathrm{Cr}$-labeled beads were used to determine time frames for these pathways. The first pathway, involving extracellular digestion and intestinal uptake, is relatively inefficient in the digestion of bacterial cells by $P$. amurensis but more efficient in $M$. balthica. The second pathway, involving intracellular digestion within the digestive gland of both clams, was highly efficient in absorbing bacterial carbon, and was responsible for most chromium uptake. Differences in the overall retention of microbial ${ }^{51} \mathrm{Cr}$ and ${ }^{14} \mathrm{C}$ relate not to gut-passage times but to the processing and release strategies of the food material by these 2 clams.
\end{abstract}

\section{INTRODUCTION}

Digestive processing of ingested particles may affect how bivalves obtain nutrition and accumulate pollutants (Phillips 1979, Borchardt 1985, Spacie \& Hamelink 1985). The processing of potential food material in deposit- and suspension-feeding bivalves involves several steps. At each of these steps, material may be rejected or further processed. Once food material enters via the siphon, the initial processing involves a physical sorting usually based on particle size, density, or perhaps quality (see Bayne \& Newell 1983 for review). The gills can act as the particle sieve, generally concentrating the smaller, more organic-rich particles. These are ferried to the mouth and stomach. Larger, less desirable particles are rejected as pseudofeces through the incurrent siphon or mantle, often bound by mucus.

Further sorting occurs after food material has entered the stomach and digestion has begun. Digestive enzymes released by the crystalline style begin to degrade labile organic material extracellularly. Subsequent absorption of solute or colloidal organic material (and associated metals) may occur across the membranes of the stomach and intestine. This has been called 'intestinal digestion' (sensu Widdows et al. 1979). Finer particulate material is thought to be further sorted from these solutes while in the stomach. These fine particulates may be held within the stomach diverticular folds (if present), then sent to the tubules of the digestive gland. Here digestive cells phagocytize the particles and digest them intracellularly (i.e. 'glandular digestion'; Widdows et al. 1979). The relative importance of extracellular and intracellular digestion in carbon absorption or trace metal uptake by bivalves has been a source of speculation (Luoma 1983, 1989), but is not well understood. Determining the mechanisms whereby benthos absorb carbon is crucial to defining nutritionally viable carbon sources in sediments and understanding carbon cycling. The relative importance of food and water as sources of trace metal pollutants is an on-going subject 
of controversy (Luoma et al. in press), partly because the mechanisms of digestive uptake are not known.

In the present study we compared the time course for release of ingested food material in the feces of a facultative deposit-feeding bivalve and a suspensionfeeder. Our purpose was to determine if the 2 patterns of digestion (i.e. intestinal and glandular) were detectable in the release of fecal material, and to assess adsorption of carbon and adsorbed metal (Cr-III) from microbial cells during such processes. Few previous studies have directly compared digestive processing in morphologically dissimilar bivalves, especially with regard to its effect on metal absorption.

The 2 bivalves chosen, Potamocorbula amurensis and Macoma balthica, co-occur in San Francisco Bay. California, USA. P. amurensis is a suspension-feeder that was introduced to the Bay in 1986 (Carlton et al. 1990). Since then, it has rapidly spread throughout the system (Nichols et al. 1990). Its rapid growth rates and numerical dominance make it a potentially important component in the carbon dynamics and metal cycling within the Bay system, but almost nothing is known about its feeding requirements or metal uptake. $M$. balthica is morphologically a deposit-feeding species which is capable of suspension-feeding. Various aspects of its feeding ecology (Newell 1965, Tunnicliffe \& Risk 1977. Harvey \& Luoma 1985) and accumulation of metals have been examined (Luoma et al. 1985, Cain \& Luoma 1986, Johns \& Luoma 1990), but the role of digestive processing in uptake of metals has not been considered.

\section{METHODS}

Experimental specimens. The clam Macoma balthica was collected from an intertidal mudflat in south San Francisco Bay (Station \#5, in Luoma et al. 1985). Individuals of the Asian clam Potamocorbula amurensis were collected from an intertidal mudflat in the Carquinez strait (Station \#M1, in Johns et al. 1988).

Clams were kept in the laboratory at $20 \%$ salinity and $10^{\circ} \mathrm{C}$ temperature for 1 to $4 \mathrm{~d}$ in microcosms containing sediments collected from the same site as the specimens and fed daily (described below). All clams used in experiments were of similar size (range $=1.4$ to $1.7 \mathrm{~cm}$ length). Seawater used in experimental procedures was collected from a coastal site near the Long Marine Facility (Univ. of California at Santa Cruz).

'Natural food material', consisting of surface sediment, was collected from the same areas as the clams. The sediment was vigorously suspended in seawater, then allowed to settle for $5 \mathrm{~min}$. The portion remaining in suspension, which was readily ingested by both Potamocorbula amurensis and Macoma balthica, was used for daily food additions to microcosms. Microscopic examination of this material indicated that it contained diatoms and other microalgae, bacteria, fine sediment and organic detrital particles. The concentrations of sediment suspensions were purposefully kept dilute to reduce the production of pseudofeces by the clams upon ingestion.

Feeding experiments. In order to analyze the movement of ingested food material through the digestion process, 2 types of pulse-chase radiotracer feeding experiments were employed (Fig. 1): In the first type of experiment, clams were fed radioactive $\left({ }^{51} \mathrm{Cr}\right)$ beads refractory to digestion which served as an inert tracer to determine at what times and at what rates undigested particles were released from the clam digestive system. In the second type of experiment, radioactively-labeled $\left({ }^{14} \mathrm{C}\right.$ and ${ }^{51} \mathrm{Cr}$ ) bacterial cells were fed to the clams to determine processing and absorption from this type of food material.

${ }^{51}$ Cr-bead feeding experiments. Material inert to digestion was fed to the clams as latex beads impregnated with ${ }^{51} \mathrm{Cr}$ radionuclide (NEN Research Products; Specific Activity $=46 \mathrm{dpm}$ per bead). The beads are 15 $\mu \mathrm{m}$ in diameter (a typical size for food particles) and were readily ingested and retained by the clams when added with a sediment suspension

To commence a pulse-chase experiment, 10 to 14 clams were placed in a microcosm containing $600 \mathrm{ml}$ $\mathrm{SW}$. They were allowed to acclimate to the container for $0.5 \mathrm{~h}$ in the presence of natural suspensions. Then a suspension of ${ }^{51} \mathrm{Cr}$-beads was added to the water and briefly mixed with the food. After this 'hot' feed $(10 \mathrm{~min}$ for Potamocorbula amurensis and $2 \mathrm{~h}$ for Macoma balthica), the clams were removed, rinsed, and placed in glass vials containing SW for gamma counting (1 min each) to determine what quantities of ${ }^{51} \mathrm{Cr}$ beads had been ingested. Labeled material remaining in the scintillation vials after counting was considered pseudofeces. The clams which fed during the hot-feed incubation were placed separately in 'cold-feed' microcosms for up to $7 \mathrm{~d}$. Natural food suspensions were added to each microcosm every hour for $P$. amurensis and every 6 to $8 \mathrm{~h}$ for $M$. balthica, and seawater was changed every $12 \mathrm{~h}$. Pseudofeces and fecal pellets from each individual were collected separately at preset time intervals and analyzed for ${ }^{51} \mathrm{Cr}$. The preset time intervals used in the collection of fecal pellets differed in the 2 bivalves because preliminary experiments indicated large differences in the gutpassage times of the 2 species.

For Potamocorbula amurensis, fecal pellets were collected by pipette every 10 to 15 min for the first $6 \mathrm{~h}$ of cold feeding. After $6 \mathrm{~h}$, pellets were collected at $8 \mathrm{~h}$ intervals for up to $7 \mathrm{~d}$. The number of pellets produced at each interval was noted. The bead concentration 
PROCEDURE

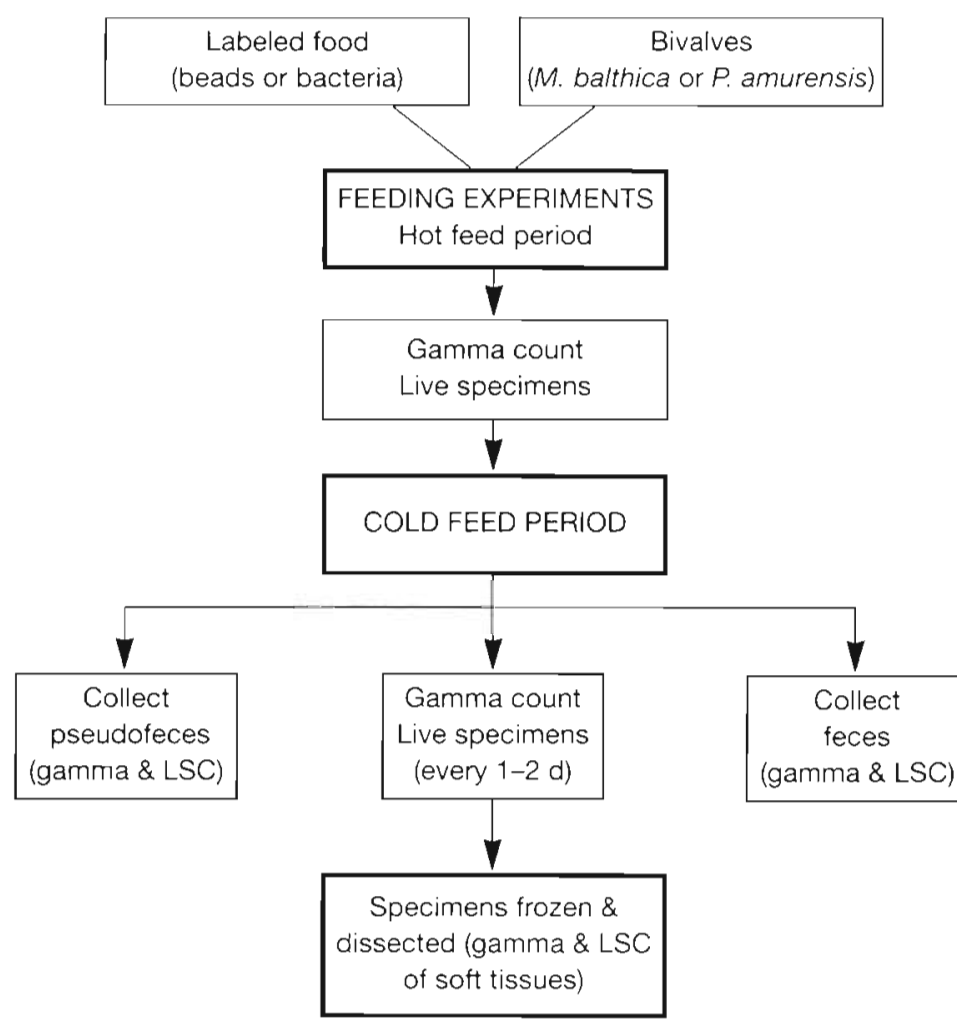

DESCRIPTION

Bivalves feed on labeled food material

(P. amurensis: $10 \mathrm{~min}$ )

(M. balthica: $30 \mathrm{~min}$ )

Determine 'Total ingested label' during 'Hot-feed period'

Bivalves feed on unlabeled food material. Periodic collection of feces \& pseudofeces, and gamma counts of live specimens

Final tissue label counts after $7 d$

Fig. 1 Design of feeding experiments using the bivalves Potamocorbula amurensis and Macoma balthica. Food material, represented by inert ${ }^{51} \mathrm{Cr}$-beads or ${ }^{51} \mathrm{Cr}$ - and ${ }^{14} \mathrm{C}$-labeled bacterial cells, were fed to clams in the presence of natural food suspensions to trace ingestion, retention and egestion pathways

at the start of the feeding experiment was $2956 \pm 427$ $\left(\bar{x} \pm \mathrm{SE}_{\overline{\mathrm{x}} ;} \mathrm{n}=3\right)$ beads $\mathrm{ml}^{-1}$.

For Macoma balthica, fecal pellets were collected every $1 \mathrm{~h}$ for the first $36 \mathrm{~h}$ of cold feeding Subsequently, pellets were collected every $12 \mathrm{~h}$ for up to $7 \mathrm{~d}$. The number of pellets produced at each interval was noted. The bead concentration at the start of the feeding experiments were $1521 \pm 385(\mathrm{n}=3$ ) beads $\mathrm{ml}^{-1}$. Whole-animal counts of both bivalves were conducted every $24 \mathrm{~h}$.

Labeled bacterial cell feeding experiments. The second type of feeding experiments utilized bacterial cells as an example of natural foods which the clams consume (Newell 1965). Pulse-chase procedures employed for both species were similar to experiments using inert beads except that Macoma balthica was allowed to 'hot-feed' for $30 \mathrm{~min}$. The common marine bacterium Pseudomonas atlantica, obtained from the American Type Culture Collection (Washington, D. C.), was grown in laboratory culture using $125 \mathrm{ml}$ flasks. The culture media contained $0.5 \%$ (wt./vol.) dextrose, $0.2 \%$ bacto-peptone in filtered $(0.2 \mu \mathrm{m})$ seawater ( $25 \%$ salinity). Cultures were grown at 22 to $23^{\circ} \mathrm{C}$ on a mechanical shaker. During the early log phase of growth, $500 \mu \mathrm{Ci}$ of $(\mathrm{U})-{ }^{14} \mathrm{C}$-D-glucose was added to the cultures. Cultures were harvested by fixation in $0.5 \%$ (vol./vol.) formalin during late log phase of growth ( $5 \mathrm{~d})$, then washed several times by centrifugation $(12000 \times g)$ in filtered $(0.2 \mu \mathrm{m})$ seawater. Cell numbers were monitored by direct counts (Hobbie et al. 1977). ${ }^{51} \mathrm{Cr}$ (ICN Radiochemical Co.) was adsorbed to the formalin-fixed cells by addition of $5 \mu \mathrm{Ci}^{51} \mathrm{CrCl}_{2}$ for $2 \mathrm{~h}$. Cells were washed several times by centrifugation in filtered seawater ( $\mathrm{pH} 7.8)$, then mixed with sediment suspensions. Activities were determined by measuring known triplicate aliquots using LSC and gamma counting.

Respiration of ${ }^{14} \mathrm{C}$-label. Respiration losses of ${ }^{14} \mathrm{CO}_{2}$-label by the clams during the feeding experiments was monitored according to methods modified from Hobbie \& Crawford (1969). Fifteen clams, previously fed ${ }^{14} \mathrm{C}$-labeled bacterial cells, were placed in enclosed vials containing seawater and sediment suspensions. Three vials (respiration-control vials) contained labeled bacterial cells suspensions in similar concentrations to hot-feed chambers, but contained 
no clams. All vials were fitted with injection ports and suspended folded-chromatography paper (Whatman No. 1) for collection of ${ }^{14} \mathrm{CO}_{2}$ using phenylethylamine (Hobbie \& Crawford 1969). Sets of 3 replicate clams were incubated for $4 \mathrm{~h}$, beginning at the start of the cold-feed period $\left(\mathrm{T}_{0}\right)$ and $4 \mathrm{~h}$ after the start $\left(T_{4}\right)$. Once respiration incubations were completed, clams were retrieved, washed and prepared for liquid scintillation counting (LSC). Trapping efficiency, measured in preliminary experiments using $\mathrm{NaH}^{14} \mathrm{CO}_{3}$ standards, was $97.0 \%$. From these results loss rate curves of ${ }^{14} \mathrm{CO}_{2}$ over time were calculated. Losses due to respiration of ${ }^{14} \mathrm{CO}_{2}$ during experimental time frame were included in the calculations of absorption efficiency (see below).

Gamma and liquid scintillation counting. Samples were analyzed for ${ }^{51} \mathrm{C}$ using a gamma counter equipped with a thallium-activated Na-iodide crystal detector. Samples were analyzed for ${ }^{14} \mathrm{C}$ on a liquid scintillation counting system, using ScintiVerse II (Fisher Sci. Co.) as the scintillation cocktail. Clam tissues (minus the shell) and feces were solubilized using $1.0 \mathrm{ml}$ ScintiGest (Fisher $\mathrm{Co}$.) before analysis. Quenching was corrected for using the external standards ratio method. The isotope ${ }^{51} \mathrm{Cr}$ (half-life $=27.8 \mathrm{~d}$ ) additionally produces a beta-signal (via electron capture) which is detectable by LSC. Because this signal partially overlaps with that of ${ }^{14} \mathrm{C}$, all samples containing both ${ }^{14} \mathrm{C}$ and ${ }^{51} \mathrm{Cr}$ were initially gamma counted then allowed to decay for $4{ }^{51} \mathrm{Cr}$ half-lives before counting of ${ }^{14} \mathrm{C}$ was conducted.

Calculation of absorption efficiency. Absorption efficiency was calculated from both whole body counts before and after egestion, and using a mass balance approach (Lopez et al. 1989). Terms used frequently in the calculation of absorption efficiencies and the rest of the text are:

Body-label $\left(B_{i}\right)$ : The amount of label present in clam tissues (including the shell) after egestion of labeled food material. Corrections for ${ }^{14} \mathrm{CO}_{2}$ losses through respiration were included.

Final tissue-label $\left(T_{i}\right)$ : The amount of label present in clam tissues (minus the shell) after egestion of labeled food material. Corrections for ${ }^{14} \mathrm{CO}_{2}$ losses through respiration were included.

Fecal-label ( $\Sigma F)$ : The summed $(\Sigma)$ total activity (dpm) in the fecal pellets egested over the course of the experiment (pseudofeces not included).

Total ingested-label $\left(T_{1}\right)$ : Initial activity directly determined by counting whole individual clams at $T_{0}$.

Actual ingested-label $\left(A_{1}\right)$ : (Total ingested label) (Pseudofeces egested during the initial phase of the experiment).

Corrected Co $\left(C_{0}\right)$ : Calculated as $T_{f}+\Sigma F$ (pseudofeces and solute label not included)
Absorption efficiencies ( $\% \mathrm{AE}$ ) were then calculated as:

$$
\begin{array}{llll}
\text { Body } \% \mathrm{AE}= & \frac{\mathrm{B}_{\mathrm{i}}}{\mathrm{A}_{1}} \quad & \text { (for }{ }^{51} \mathrm{Cr} \text { only) } \\
\text { Tissue } \% \mathrm{AE}= & \frac{\mathrm{T}_{1}}{\mathrm{~A}_{1}} \quad\left(\text { for }{ }^{51} \mathrm{Cr}\right. \text { only) } \\
\text { Fecal } 1 \% \mathrm{AE}= & 1-\frac{(\Sigma F)}{\mathrm{A}_{1}} & \text { (for }{ }^{51} \mathrm{Cr} \text { only) } \\
\text { Fecal } & \% \mathrm{AE}= & 1-\frac{\left(\sum F\right)}{\mathrm{C}_{0}} & \text { (for }{ }^{14} \mathrm{C} \text { only) }
\end{array}
$$

Results from absorption efficiency experiments were compared between bivalve species and between elements $\left({ }^{14} \mathrm{C}\right.$ and $\left.{ }^{51} \mathrm{Cr}\right)$. Percent absorption efficiency data were arcsin transformed for statistical analyses. Comparisons were then analyzed using a 2-way factorial design ANOVA for unequal sample sizes (Sokal \& Rohlf 1981). A posteriori tests of significant interaction terms were conducted using Duncan's Multiple Range tests (Steele \& Torrie 1980). Linear regressions were used to determine the rates of egestion (i.e. slopes and $\mathrm{R}^{2}$ values) for each of these digestion phases for both species of clams. The 'half-life' $\left(t_{1 / 2}\right)$ of ${ }^{14} \mathrm{C}$ and ${ }^{51} \mathrm{Cr}$ labels in both clams were calculated for each time interval (Shipley \& Clark 1972) from the equation:

$$
t_{1 / 2}=0.693 / k
$$

where $t_{1 / 2}=$ time needed for a $50 \%$ decrease in label; and $k=$ proportional loss rate per unit time determined by semi-log regression (Riggs 1963). The gut-passage rates of ${ }^{51} \mathrm{Cr}$-cells were compared to passage rates of ${ }^{51} \mathrm{Cr}$-beads using a 2-way factorial ANOVA for unequal sample sizes (Sokal \& Rohlf 1981) after logtransformation of data. Minimum gut-passage time was measured rather than the mean gut passage time. This was defined as the difference in time between initial ingestion of 'radiolabeled' food and the first appearance of the radiolabel in the fecal pellets. All data transformations and analyses were conducted using the SYSTAT statistical analysis system (Wilkinson 1987).

\section{RESULTS}

\section{Potamocorbula amurensis}

Inert-bead feeding experiments. During the $10 \mathrm{~min}$ exposure to inert ${ }^{51} \mathrm{Cr}$-beads, the clams ingested 25164 $\pm 4933\left(\bar{x} \pm \mathrm{SE}_{\bar{x}}, \mathrm{n}=10\right)$ beads per individual. During the first $12 \mathrm{~h}$ of cold-feeding $4.3 \pm 0.66 \%$ of the ingested bead material was released as pseudofeces (Table 1). No pseudofeces containing labeled ${ }^{51} \mathrm{Cr}$ were detected after this time. 
Table 1. Potamocorbula amurensis and Macoma balthica mean ingestion of 'inert ${ }^{51} \mathrm{Cr}$-beads' by bivalves. Values represent mean $\left( \pm \mathrm{SE}_{x}\right){ }^{51} \mathrm{Cr}$-dpm of 'total ingested label' (including pseudofeces) and 'actual ingested label' (minus pseudofeces), by clams during 'hot' feed. PF: pseudofeces; dpm: disintegrations per minute. For further abbreviations in all tables, see 'Methods'

\begin{tabular}{|ccccc|}
\hline Species & $\begin{array}{c}\mathrm{T}_{1} \\
(\mathrm{dpm})\end{array}$ & $\begin{array}{c}\mathrm{PF} \\
(\mathrm{dpm})\end{array}$ & $\begin{array}{c}\text { \% Label } \\
\text { loss via PF }\end{array}$ & $\begin{array}{c}\text { Actual ingested } \\
(\mathrm{dpm})\end{array}$ \\
\hline P. amurensis & $1157579 \pm 226909$ & $50029 \pm 13908$ & $4 \pm 0.7$ & $1112193 \pm 215009$ \\
M. balthica & $261581 \pm 47596$ & $80982 \pm 17226$ & $39 \pm 8$ & $80598 \pm 46069$ \\
\hline
\end{tabular}

Mean minimum gut-passage time in Potamocorbula amurensis was $0.86 \pm 0.08 \mathrm{~h}(\mathrm{n}=10$; range $=0.5$ to $1.5 \mathrm{~h})$. Egestion was variable among individuals, but a 2 -phase loss was observable in nearly every clam. In a typical clam, egestion began with an initial pulse of activity in the feces between 40 to $90 \mathrm{~min}$. An average of $7.5 \%$ of the ingested activity was lost during this initial pulse. The initial pulse was followed by a period of low activity in the feces (Fig. 2A) which lasted an additional 0.25 to $1.20 \mathrm{~h}$. After this time, activity in the feces increased but egestion was irregular. After ca 24 $\mathrm{h}$ of cold-feeding release of ${ }^{51} \mathrm{C}$-beads in the feces of all individuals had dropped to near background levels. An average of $92 \%$ of the activity was lost during the more prolonged period.

\section{(A) P. amurensis}



(B) M. balthica

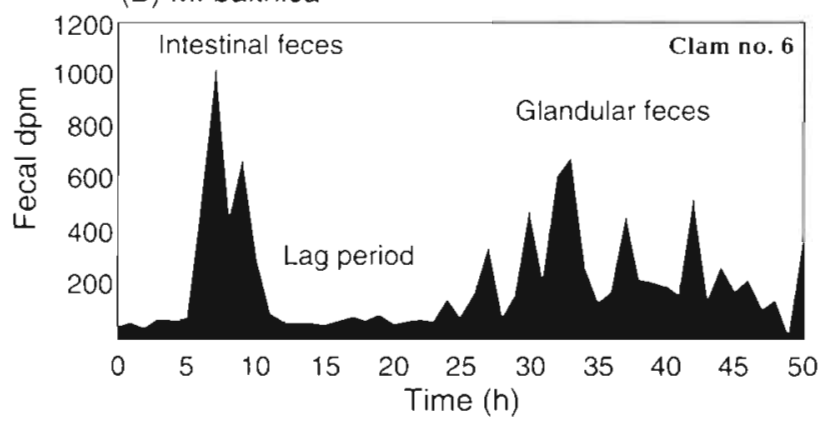

Fig. 2. Loss of ${ }^{51} \mathrm{Cr}$-beads over time in the fecal pellets from typical individuals of (A) Potamocorbula amurensis and (B) Macoma balthica. Note the distinct initial peak of egested label (i.e. intestinal feces), the 'lag period' of no significant label release and later, the more prolonged releases of label (i.e. glandular feces)
Bacterial cell feeding experiments. The concentrations of labeled cells (Pseudomonas atlantica) were $11000 \pm 1056(n=3)$ cells per $m l$ and the activity of the cells were $0.73 \mathrm{dpm}$ per cell of ${ }^{14} \mathrm{C}$ and $1.84 \mathrm{dpm}$ per cell of ${ }^{51} \mathrm{Cr}$ in this experiment. This yielded a ${ }^{14} \mathrm{C} /{ }^{51} \mathrm{Cr}$ ratio of 0.395 .

The clams ingested $162649 \pm 13934$ ( $\mathrm{n}=10$ ) bacterial cells per individual during the 10 min exposure. Labeled pseudofeces, released only during the first 12 h of cold-feeding, comprised $20.3 \%$ of the initially ingested material. After $24 \mathrm{~h}$ of egestion, $66.7 \%$ of the ingested ${ }^{51} \mathrm{Cr}$-label remained in the clams (Table 2). Thus, ${ }^{51} \mathrm{Cr}$ was not inert to absorption over the entire period of digestion. The release of ${ }^{14} \mathrm{C}$-label followed a similar time course of egestion as ${ }^{51} \mathrm{Cr}$ (Fig. 3), although ca $10 \%$ of the ingested ${ }^{14} \mathrm{C}$-label was respired during the first $8 \mathrm{~h}$ of cold-feeding

Three lines of evidence suggested neither ${ }^{14} \mathrm{C}$ nor ${ }^{51} \mathrm{Cr}$ was absorbed during the initial phase of digestion: (1) higher proportions of the bacterial labels were egested than of the inert beads during the initial phase of digestion (Fig. 3); (2) ${ }^{14} \mathrm{C} /{ }^{51} \mathrm{Cr}$ ratios were similar in food (0.395) and in feces (0.41) egested during the initial loss period (Table 3); (3) loss rates of ${ }^{51} \mathrm{Cr},{ }^{14} \mathrm{C}$ and beads were similar during the initial phase (Table 4). Thus, absorption of $\mathrm{Cr}$ and $\mathrm{C}$ was detectable only after the prolonged phase of digestion.

Examination of egestion rate curves from fecal data over $168 \mathrm{~h}$ of the experiment indicated that there were 3 distinct periods of loss (i.e. compartments; Fig. 4). The first 2 loss periods correspond to egestion of label in feces. The third compartment represents physiological loss (Fig. 4, Table 4).

\section{Macoma balthica}

Inert bead feeding experiments. During the $30 \mathrm{~min}$ 'hot-feeding' period, the clams ingested $5687 \pm 1035$ ( $n=12$ ) beads per individual. Approximately $39 \%$ of the ingested bead material was subsequently released as pseudofeces during the first $24 \mathrm{~h}$ of 'cold-feeding' (Table 1). No pseudofeces containing labeled ${ }^{51} \mathrm{Cr}$ were detected after this time. 
Table 2. Potamocorbula amurensis. Data employed to determine absorption efficiencies (AE) of ${ }^{51} \mathrm{Cr}$ from bacterial cells. Fecal-label $(\Sigma F)$ and Body-label $\left(B_{f}\right)$ determined after $24 \mathrm{~h}$ of egestion

\begin{tabular}{|c|c|c|c|c|c|c|}
\hline Clam no. & $\begin{array}{l}\% \text { Pseudo- } \\
\text { feces }\end{array}$ & $\begin{array}{c}A_{1} \\
(d p m)\end{array}$ & $\begin{array}{c}B_{f} \\
(d p m)\end{array}$ & $\begin{array}{c}\Sigma F \\
(\mathrm{dpm})\end{array}$ & $\begin{array}{l}\text { Fecal } \\
\% \mathrm{AE}\end{array}$ & $\begin{array}{l}\text { Body } \\
\% \text { AE }\end{array}$ \\
\hline 1 & 27 & 264636 & 172183 & 90421 & 65.83 & 65.06 \\
\hline 2 & 17 & 265904 & 182200 & 81694 & 69.28 & 68.52 \\
\hline 3 & 11 & 435214 & 338833 & 94337 & 78.33 & 77.85 \\
\hline 4 & 25 & 235602 & 173867 & 59722 & 74.66 & 73.79 \\
\hline 5 & 23 & 368737 & 179100 & 187605 & 49.13 & 48.57 \\
\hline 6 & 31 & 367324 & 227440 & 137856 & 62.48 & 61.91 \\
\hline 7 & 18 & 180954 & 134425 & 44516 & 75.40 & 74.28 \\
\hline 8 & 16 & 262830 & 198550 & 62255 & 76.32 & 75.54 \\
\hline 9 & 20 & 361567 & 262325 & 97230 & 73.11 & 72.55 \\
\hline 10 & 15 & 250234 & 103000 & 145209 & 41.98 & 41.16 \\
\hline $\bar{x} \pm \mathrm{SE}_{\bar{x}}$ & $20 \pm 2$ & $299300 \pm 24943$ & $198192 \pm 21032$ & $100085 \pm 14041$ & $66.65 \pm 3.87$ & $65.92 \pm 3.87$ \\
\hline
\end{tabular}

The mean minimum gut-passage time for Macoma balthica was $9.6 \pm 1.8 \mathrm{~h}(\mathrm{n}=13)$; range $=3$ to $16 \mathrm{~h})$. The 2-phase nature of loss was observable in nearly every individual of this species. The pattern of egestion was similar to Potamocorbula amurensis, but the duration of each phase was longer (Fig. 2B). In a typical clam, egestion commenced with an initial pulse of activity in

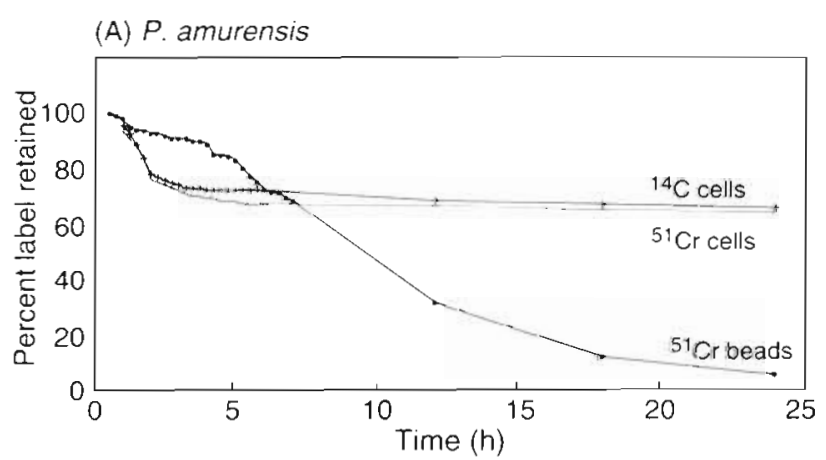

(B) M. balthica

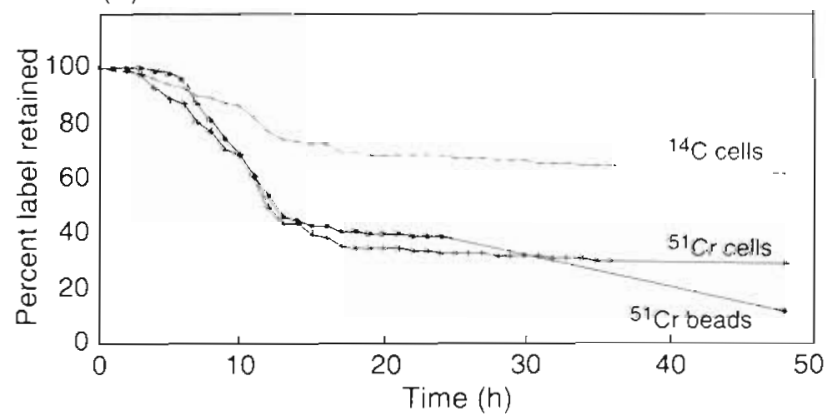

Fig. 3. Mean percent egestion of label (in fecal pellets) versus time in the bivalves (A) Potamocorbula amurensis and (B) Macoma balthica. In separate experiments, the clams were fed either ${ }^{51} \mathrm{Cr}$-beads or ${ }^{51} \mathrm{Cr}$ - and ${ }^{14} \mathrm{C}$-bacterial cells. Each data point for the $P$. amurensis graph represents the mean of $\mathrm{n}=10$ individuals; each data point for the $M$. balthica graph represents the mean of $n=13$ individuals the feces between 3 and $12 \mathrm{~h}$. An average of $56 \%$ of the ingested activity was lost during this initial pulse. The initial pulse was followed by a period of low activity (Fig. 2B) which lasted 4 to $15 \mathrm{~h}$. After this time, activity in the feces increased. An average of $44 \%$ of the label was lost during the more prolonged egestion period that followed. By 72 to $96 \mathrm{~h}$, greater than $95 \%$ of the label had been released and ${ }^{51} \mathrm{Cr}$ in the feces dropped to near-background levels for the duration of the feeding experiments

In certain individuals a brief cessation of feeding occurred for one to several hours during the coldfeeding period of the bead experiments, which added to variabilities in release rates among individuals.

Bacterial cell feeding experiments. Initial concentrations of labeled bacterial cells were $5111 \pm 967$ ( $\mathrm{n}=$ 3) cells $\mathrm{ml}^{-1}$. The activities of the cells were $2.50 \mathrm{dpm}$ cell ${ }^{-1}$ of ${ }^{14} \mathrm{C}$ and $2.18 \mathrm{dpm}$ cell ${ }^{-1}$ of ${ }^{51} \mathrm{Cr}$. This yielded a ${ }^{14} \mathrm{C} /{ }^{51} \mathrm{Cr}$ ratio of 1.15 .

The clams ingested $18776 \pm 3340(n=13)$ cells per individual during the 30 min exposure. Approximately 27 to $28 \%$ of the initially ingested ${ }^{14} \mathrm{C}$ and ${ }^{51} \mathrm{Cr}$ material was released as pseudofeces during the first 24 h of the cold-feeding period (Table 5). No labeled pseudofeces were detected after this time. Approximately $4 \%$ of the ingested ${ }^{14} \mathrm{C}$-label was respired as ${ }^{14} \mathrm{CO}_{2}$ during the first $8 \mathrm{~h}$ of cold-feeding

Egestion of ${ }^{51} \mathrm{Cr}$ and ${ }^{14} \mathrm{C}$ occurred at different rates in Macoma balthica (Fig. 3). Bacterial ${ }^{51} \mathrm{Cr}$ was egested at the same rate as the inert beads during the first $12 \mathrm{~h}$, suggesting no absorption of bacterial $\mathrm{Cr}$ occurred during initial digestion. However, most bacterial ${ }^{51} \mathrm{Cr}$ that entered the prolonged phase of digestion appeared to be retained. In contrast ${ }^{14} \mathrm{C}$ was egested at a slower rate during the initial phase than were the inert beads. Differences between the 2 curves at $12 \mathrm{~h}$ indi- 
Table 3. Potamocorbula amurensis. Data employed to calculate absorption efficiency (AE) of ${ }^{14} \mathrm{C}$ from bacterial cells. I-fecal: feces collected during 'initial' loss period. $\Sigma F$ determined after $24 \mathrm{~h}$ of egestion

\begin{tabular}{|c|c|c|c|c|c|}
\hline Clam no. & $\begin{array}{l}\% \text { Pseudo- } \\
\text { feces }\end{array}$ & $\begin{array}{c}\mathrm{C}_{0} \\
(\mathrm{dpm})\end{array}$ & $\begin{array}{c}{ }^{14} \mathrm{C} / \mathrm{Cr} \\
\text { I-fecal }\end{array}$ & $\begin{array}{c}\sum F \\
\text { (dpm) }\end{array}$ & $\begin{array}{l}\text { Fecal } \\
\% \mathrm{AE}\end{array}$ \\
\hline 1 & 28 & 103208 & 0.39 & 38187 & 63.0 \\
\hline 2 & 16 & 127634 & 0.48 & 22974 & 82.1 \\
\hline 3 & 13 & 121859 & 0.28 & 17159 & 85.9 \\
\hline 4 & 25 & 91884 & 0.39 & 26646 & 71.1 \\
\hline 5 & 25 & 117995 & 0.32 & 51947 & 55.9 \\
\hline 6 & 33 & 165295 & 0.45 & 38218 & 76.8 \\
\hline 7 & 16 & 85048 & 0.47 & 15108 & 82.2 \\
\hline 8 & 17 & 120901 & 0.46 & 32643 & 73.0 \\
\hline 9 & 22 & 144626 & 0.40 & 30171 & 79.1 \\
\hline 10 & 16 & 105098 & 0.42 & 16616 & 84.2 \\
\hline $\bar{x} \pm \mathrm{SE}_{x}$ & $21 \pm 2$ & $118355 \pm 7611$ & $0.41 \pm 0.02$ & $28966 \pm 3710$ & $75.3 \pm 3.1$ \\
\hline
\end{tabular}

cated ca $30 \%$ absorption efficiency of ${ }^{14} \mathrm{C}$ during this initial phase of digestion. Comparisons of the ${ }^{14} \mathrm{C} /{ }^{51} \mathrm{Cr}$ ratios (Table 6) from food (1.15) and initially egested material (0.77) yielded a similar result $(33.1 \pm 14.1 \%$ AE). After respiration was considered, overall carbon absorption from the bacterial source was $68.4 \pm 3 \%$ (Table 6), similar to that observed for Potamocorbula amurensis. Absorption of ${ }^{51} \mathrm{Cr}$ was approximately half that observed in $P$. amurensis (Table 7).

Three distinct loss periods were also separable by regression analysis in Macoma balthica (Fig. 4B). Halftimes of loss $\left(t_{1 / 2}\right)$ were longer than observed for Potamocorbula amurensis (Table 4), indicative of the longer duration of each phase of digestion in $M$. balthica than in $P$. amurensis. Differences in $t_{1 / 2}$ values between ${ }^{14} \mathrm{C}$ and ${ }^{51} \mathrm{Cr}$ further substantiated $\mathrm{C}$ absorption in the initial phase of loss.

Statistical comparisons. Results of ANOVAs analyzing minimum gut-passage times indicated a highly significant $(p<0.001)$ main effect difference between the 2 bivalve species (Potamocorbula amurensis, $\bar{x}=$ $51.7 \mathrm{~min} ;$ Macoma balthica, $\bar{x}=9.61 \mathrm{~h}$ ). There was no significant $(p=0.510)$ difference, however, between the minimum gut-passage rates for ${ }^{51} \mathrm{Cr}$-cells vs ${ }^{51} \mathrm{Cr}$ beads in either $P$. amurensis or $M$. balthica. When the 2 bivalves were fed the same food at similar concentrations, $P$. amurensis also processed a higher proportion (75 to $90 \%$ ) of its food through the glandular phase than $M$. balthica $(40 \%)$.

Analyses of absorption efficiencies by a 2-way

Table 4. Macoma balthica and Potamocorbula amurensis. Half-lives $\left(t_{1 / 2}\right.$, in $\left.\mathrm{h}\right)$, loss-rates $\left(\mathrm{h}^{-1}\right)$, slopes $(\beta)$, and $\mathrm{R}^{21} \mathrm{~s}$ of ${ }^{14} \mathrm{C}$ and ${ }^{51} \mathrm{Cr}$ labels for the 3 pathways (intestinal, glandular, and physiological) in clams fed bacterial cells and inert beads

\begin{tabular}{|c|c|c|c|}
\hline \multirow[t]{3}{*}{ Loss period } & \multicolumn{3}{|c|}{ Food type } \\
\hline & \multirow{2}{*}{$\begin{array}{c}\text { Beads } \\
t_{1 / 2}\left({ }^{51} \mathrm{Cr}\right)\end{array}$} & \multicolumn{2}{|c|}{ Bacterial cells } \\
\hline & & $t_{1 / 2}\left({ }^{51} \mathrm{Cr}\right)$ & $t_{1 / 2}\left({ }^{14} \mathrm{C}\right)$ \\
\hline \multicolumn{4}{|l|}{ Macoma balthica } \\
\hline Intestinal $(3-17 \mathrm{~h})$ egestion & $\begin{array}{c}13.1 \\
\left(\beta=0.053, R^{2}=0.96\right)\end{array}$ & $\begin{array}{c}8.6 \\
\left(\beta=0.081, R^{2}=0.97\right)\end{array}$ & $\begin{array}{c}26.6 \\
\left(\beta=0.026, R^{2}=0.98\right)\end{array}$ \\
\hline Glandular $(18-72 \mathrm{~h})$ egestion & $\begin{array}{c}49.5 \\
\left(\beta=0.014, R^{2}=0.95\right)\end{array}$ & $\begin{array}{c}115 \\
\left(\beta=0.006, R^{2}=0.93\right)\end{array}$ & $\begin{array}{c}138 \\
\left(\beta=0.005, R^{2}=0.96\right)\end{array}$ \\
\hline Physiological loss (> $72 \mathrm{~h}$ ) & - & $\begin{array}{c}138 \\
\left(\beta=0.005, R^{2}=0.99\right)\end{array}$ & $\begin{array}{c}231 \\
\left(\beta=0.003, R^{2}=0.98\right)\end{array}$ \\
\hline \multicolumn{4}{|l|}{ Potamocorbula amurensis } \\
\hline Intestinal $(0.2-1.7 \mathrm{~h})$ egestion & $\begin{array}{c}5.2 \\
\left(\beta=0.134, R^{2}=0.98\right)\end{array}$ & $\begin{array}{c}5.9 \\
\left(\beta=0.116, R^{2}=0.87\right)\end{array}$ & $\begin{array}{c}5.1 \\
\left(\beta=0.136 \cdot R^{2}=0.80\right)\end{array}$ \\
\hline Glandular $(1.75-24 \mathrm{~h})$ egestion & $\begin{array}{c}27.7 \\
\left(\beta=0.025, R^{2}=0.81\right)\end{array}$ & $\begin{array}{c}99 \\
\left(\beta=0.007, R^{2}=0.64\right)\end{array}$ & $\begin{array}{c}69 \\
\left(\beta=0.010, R^{2}=0.84\right)\end{array}$ \\
\hline Physiological loss (> 24 h) & - & $\begin{array}{c}693 \\
\left(\beta=0.001, R^{2}=0.93\right)\end{array}$ & $\begin{array}{c}693 \\
\left(\beta=0.001, R^{2}=0.97\right)\end{array}$ \\
\hline
\end{tabular}


(A) P. amurensis



(B) M. balthica

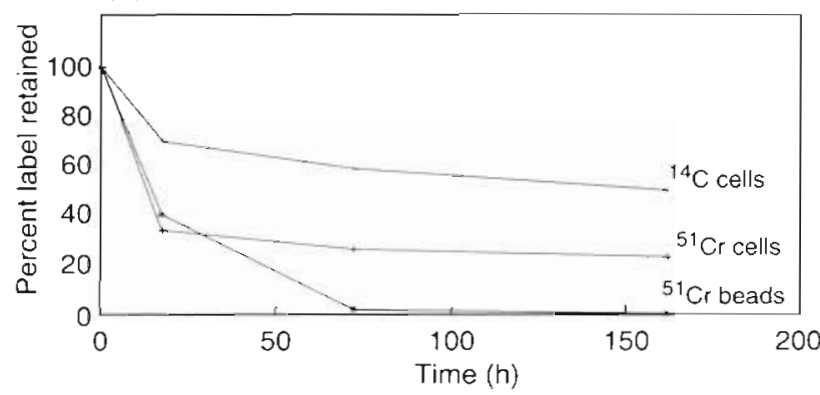

Fig. 4. Regression lines showing 3-compartment loss of label from (A) Potamocorbula amurensis and (B) Macoma balthica. Slopes (b) and $R^{2}$ values for each of the lines are given in Table 4

factorial ANOVA using arcsine-transformed data also showed significant main effects for the 2 bivalve species $(p<0.001)$ and the type of label (i.e. ${ }^{14} \mathrm{C},{ }^{51} \mathrm{Cr}$ ) $(p<0.001)$. A significant $(p<0.001)$ interaction term was also evident. A posteriori analysis of this term using Duncan's Multiple Range test, with pre-adjusted $\alpha$ values, indicated the interaction term resulted from the significantly lower absorption efficiency of ${ }^{51} \mathrm{Cr}$ by Macoma balthica.

\section{DISCUSSION}

This study supports previous work showing that bivalves sort food material into a rapidly processed fraction with a low absorption efficiency and a more slowly processed component with a higher absorption efficiency (Bayne \& Newell 1983). The biphasic digestion process was evident in both the deposit feeder Macoma balthica and the suspension feeder Potamocorbula amurensis. The distribution of food between the digestive phases affected overall absorption of $\mathrm{C}$ and $\mathrm{Cr}$. It also explained differences in metal absorption between the species.

The rapidly processed fraction of food in bivalve and gastropod species represents a compartment in which ingested food, that enters the stomach, is passed to the intestine and then released as 'intestinal feces' (Calow 1975, Purchon 1977. Widdows et al. 1979, Bricelj et al. 1984). Extracellular digestion predominates during intestinal digestion. At least some bivalves have lysozymes which can degrade bacteria extracellularly within the stomach when coenzymes are present and $\mathrm{pH}$ is optimal (Prieur et al. 1990). Extracellular lysis of bacterial cells occurred within 15 min in Mytilus edulis (Prieur 1981). Dissolved material from these cells was assimilated (Birkbeck \& McHenery 1982), and incorporated into mantle and gill tissues after $1 \mathrm{~h}$ (McHenery \& Birkbeck 1985). Intact cells and cell wall components from lysed cells were then passed to the digestive gland for further degradation. Such studies have not compared extracellular digestion among species. Nor have they compared assimilation of different elements during extracellular digestion.

Table 5. Macoma balthica. Data employed to calculate absorption efficiency (AE) of ${ }^{51} \mathrm{Cr}$ from bacterial cells. $\Sigma F e c a l$ and Bodylabel determined after $72 \mathrm{~h}$ of egestion

\begin{tabular}{|c|c|c|c|c|c|c|}
\hline Clam no. & $\begin{array}{l}\% \text { Pseudo- } \\
\text { feces }\end{array}$ & $\begin{array}{c}A_{1} \\
(\mathrm{dpm})\end{array}$ & $\begin{array}{c}\mathrm{B}_{1} \\
(\mathrm{dpm})\end{array}$ & $\begin{array}{c}\sum F \\
(\mathrm{dpm})\end{array}$ & $\begin{array}{l}\text { Fecal } \\
\% \mathrm{AE}\end{array}$ & $\begin{array}{l}\text { Body } \\
\% \mathrm{AE}\end{array}$ \\
\hline 1 & 32 & 24939 & 5586 & 18705 & 25.0 & 22.4 \\
\hline 2 & 21 & 25290 & 6045 & 17956 & 29.0 & 23.9 \\
\hline 3 & 17 & 45285 & 5071 & 38501 & 15.1 & 11.7 \\
\hline 4 & 41 & 34134 & 18023 & 15001 & 56.1 & 52.8 \\
\hline 5 & 36 & 53811 & 13829 & 37668 & 29.5 & 25.7 \\
\hline 6 & 27 & 36836 & 23207 & 12256 & 66.7 & 63.0 \\
\hline 7 & 32 & 26520 & 1824 & 23635 & 12.4 & 6.9 \\
\hline 8 & 46 & 15175 & 1761 & 12959 & 16.0 & 11.6 \\
\hline 9 & 22 & 115360 & 26201 & 85467 & 25.9 & 22.7 \\
\hline 10 & 29 & 65436 & 12791 & 49208 & 24.8 & 19.5 \\
\hline 11 & 13 & 18540 & 7953 & 9456 & 49.0 & 42.9 \\
\hline 12 & 26 & 37278 & 10337 & 25077 & 32.7 & 27.7 \\
\hline 13 & 11 & 34733 & 12608 & 20493 & 41.0 & 36.3 \\
\hline $\bar{x} \pm S E_{x}$ & $27 \pm 2$ & $41025 \pm 7299$ & $11172 \pm 2135$ & $28183 \pm 5781$ & $32.6 \pm 4.5$ & $28.2 \pm 4.6$ \\
\hline
\end{tabular}


Table 6. Macoma balthica. Data employed to calculate absorption efficiency (AE) of ${ }^{14} \mathrm{C}$ from bacterial cells. I-fecal: feces collected during 'initial' loss period. $\Sigma F$ determined after $72 \mathrm{~h}$ of egestion

\begin{tabular}{|c|c|c|c|c|c|}
\hline Clam no. & $\begin{array}{l}\% \text { Pseudo- } \\
\text { feces }\end{array}$ & $\begin{array}{c}C_{0} \\
(\mathrm{dpm})\end{array}$ & $\begin{array}{l}{ }^{14} \mathrm{C} /{ }^{51} \mathrm{Cr} \\
\text { I-fecal }\end{array}$ & $\begin{array}{c}\Sigma F \\
\text { (dpm) }\end{array}$ & $\begin{array}{l}\text { Fecal } \\
\% \triangle \mathrm{A}\end{array}$ \\
\hline 1 & 30 & 44402 & 0.66 & 6973 & 84.3 \\
\hline 2 & 26 & 21842 & 0.83 & 8147 & 62.7 \\
\hline 3 & 18 & 72591 & 0.8 .1 & 18862 & 74.0 \\
\hline 4 & 39 & 30883 & 0.83 & 6875 & 77.4 \\
\hline 5 & 37 & 57735 & 0.86 & 37796 & 34.5 \\
\hline 6 & 26 & 28838 & 0.63 & 1709 & 94.1 \\
\hline 7 & 34 & 29968 & 0.85 & 1423 & 61.8 \\
\hline 8 & 44 & 32707 & 0.72 & 5732 & 82.5 \\
\hline 9 & 23 & 91562 & 0.71 & 43402 & 52.6 \\
\hline 10 & 30 & 83475 & 0.91 & 27753 & 66.7 \\
\hline 11 & 14 & 24811 & 0.73 & 3747 & 84.9 \\
\hline 12 & 25 & 50375 & 0.71 & 12642 & 74.9 \\
\hline 13 & 12 & 41410 & 0.74 & 9717 & 76.5 \\
\hline $\bar{x} \pm \mathrm{SE}_{\bar{x}}$ & $27 \pm 2$ & $46969 \pm 6377$ & $0.77 \pm 0.09$ & $14983 \pm 3683$ & $68.4 \pm 3.1$ \\
\hline
\end{tabular}

In the present study, the release of rapidly processed material was identified in Macoma balthica by a single large initial pulse of label in the feces that appeared between 3 and $12 \mathrm{~h}$. Intestinal digestion was more rapid in Potamocorbula amurensis. Intestinal feces appeared in $P$. amurensis between 0.5 and $3 \mathrm{~h}$. $M$. balthica absorbed $C$ during intestinal digestion, as observed in other bivalves, but little $\mathrm{C}$ was absorbed by $P$. amurensis during this digestive phase. The longer duration of intestinal digestion in $M$. balthica may explain the more efficient extracellular $C$ absorption. Poor extracellular $\mathrm{C}$ absorption is perhaps a cost of the unusually short gut residence time in $P$. amurensis. In contrast to $\mathrm{C}$, neither species absorbed $\mathrm{Cr}$ during intestinal digestion. Very little cytosolic $\mathrm{Cr}$ would be expected in bacteria labeled after they were formalinkilled, thus the inefficient absorption during that phase is, perhaps, expected.

A significant implication of the present study is that most of the Cr absorption occurred during the glandu- lar digestion phase. Nearly all the $\mathrm{C}$ and $\mathrm{Cr}$ that passed into glandular digestion was retained by both Potamocorbula amurensis and Macoma balthica. This slower glandular phase is dominated by intracellular digestion (Purchon 1977). Intracellular digestion occurs in several continuous stages as histological changes occur through time (Owen 1974, Hawkins et al. 1983). Food particles are first phagocytized by 'digestive cells'. These cells then go through a series of maturational changes that include continuous changes in cell morphology. Once intracellular digestion is complete the outer portion of the digestive cells (i.e. residual bodies) are exocytised. The residual bodies, along with the refractory remains of the food particles, are released to the intestine then egested as 'glandular feces'. Reid \& Rauchert (1972) examined the intracellular enzymes within the digestive gland in 7 species of Macoma (though not M. balthica) and found that the acid endopeptidases, responsible for most protein digestion, have optimal activity near $\mathrm{pH} 3$.

Table 7. Potamocorbula amurensis and Macoma balthica. Summary of absorption effciencies (AE), using labeled bacterial cells Values expressed as mean $\pm \mathrm{SE}_{x}$. (\% $\mathrm{AE}=$ percent absorption efficiency; $\# 1=\% \mathrm{AE}$ calculated from activities of whole body label (see Eq. (1), in 'Methods'); \# 2 = \% AE calculated from activities of tissue-label (Eq. 2); \#3=\% AE calculated from activities of feces (Eq. 3). Superscript letters which are the same indicate AE estimates are not significantly different $(p>0.05)$

\begin{tabular}{|c|c|c|c|}
\hline Species & ${ }^{14} \mathrm{C}$ & ${ }^{51} \mathrm{Cr}$ & $\begin{array}{c}\text { Gut passage } \\
\text { time }(\mathrm{h})\end{array}$ \\
\hline $\begin{array}{l}\text { Macoma balthica } \\
\qquad(\mathrm{n}=13)\end{array}$ & $68.4 \cdot 3.1^{\mathrm{a}}$ & $\begin{array}{l}\text { (\# 1) } 28.9 \pm 4.6^{b} \\
(\# 2) 28.2 \pm 4.6^{b} \\
\text { (\# 3) } 32.6 \pm 4.5^{b}\end{array}$ & $9.6 \pm 1.8 \mathrm{~h}$ \\
\hline $\begin{array}{l}\text { Potamocorbula amurensis } \\
\qquad(\mathrm{n}=10)\end{array}$ & $75.3 \pm 3.1^{a}$ & $\begin{array}{l}\text { (\# 1) } 66.8 \pm 4.1^{\mathrm{a}} \\
\text { (\# 2) } 65.9 \pm 3.9^{\mathrm{a}} \\
\text { (\# 3) } 66.7 \pm 3.9^{\mathrm{a}}\end{array}$ & $0.86 \pm 0.8 \mathrm{~h}$ \\
\hline
\end{tabular}


Such low intracellular $\mathrm{pH}$ conditions should efficiently desorb $\mathrm{Cr}$ from bacterial cellular material thus allowing for its efficient uptake. Glandular digestion appeared to be complete within $24 \mathrm{~h}$ in $P$. amurensis and within 72 to $96 \mathrm{~h}$ in $M$. balthica. However, P. amurensis more efficientiy absorbed $\mathrm{Cr}$ from bacteria $(67 \%)$ than $M$. balthica ( $32 \%$ ) because a higher proportion of the ingested $\mathrm{Cr}$ was subjected to glandular digestion. $P$. amurensis processed 75 to $90 \%$ of the bacterial food via glandular feces, while $M$. balthica processed $40 \%$. The unusual efficiency with which P. amurensis absorbed potentially toxic bacteria-bound Cr may point out an important disadvantage of partitioning large proportions of ingested food toward glandular digestion. If the efficient absorption of $\mathrm{Cr}$ during glandular digestion applies to other metals in other foods, one might speculate that organisms capable of a high proportion of glandular digestion could be vulnerable to metals, especially in contaminated environments with marginal food supplies.

Gut passage time (GPT) affects overall absorption efficiencies in some species (Kofoed et al. 1989), but could not explain absorption of $\mathrm{C}$ and $\mathrm{Cr}$ when Potamocorbula amurensis and Macoma balthica were compared. Comparisons of GPT's and absorption efficiencies between species assume similar gut physiologies and processing of food material within the gut, both of which appear to differ between P. amurensis and $M$. balthica. While all phases of the digestive process were of significantly longer duration in $M$. balthica than in $P$. amurensis, $C$ absorption was not significantly different between the species. In fact, absorption of $\mathrm{Cr}$ was significantly more efficient is the species with the shorter total gut passage time. Absorption of carbon was similar in the 2 species because $M$. balthica absorbed an additional $30 \%$ of its carbon from bacteria during intestinal digestion. Thus, while the overall carbon assimilation did not differ between the species, the pathways by which carbon was obtained did differ Models suggest species can influence their net energy and nutrient gain by compartmentalizing different types of food material (Penry \& Jumars 1986). In this study we demonstrate such a circumstance. Bayne et al. (1989) suggested that bivalves balance variations in gut passage time and filtration rate to achieve relatively constant absorption efficiencies under different feeding conditions. Partitioning of food into digestive processes with different absorption capabilities must also be considered as a strategy for achieving such a balance. Of course, partitioning between digestive processes can be affected by food concentrations (Penry \& Jumars 1986), and we might expect a different partitioning in $P$. amurensis and $M$. balthica at different food concentrations than those we employed here.
Very little is known about the absorption efficiency from food of trace metals. Ingestion of food is the predominant pathway of uptake for some trace elements (Luoma et al. in press), and food can contribute to $\mathrm{Cr}$ uptake in at least some species (Bremer et al. 1990). The biological availability of ingested metal differs among different food types (Harvey \& Luoma 1985, Luoma et al. in press), and absorption efficiency is affected by food concentration (Borchardt 1985). We show in this study that subtle differences in the manner by which food is processed after ingestion may result in differences in $\mathrm{Cr}$ uptake among species. Further investigation of the sum effects of these processes could aid a better understanding of the differences among species in their sensitivities to metals and the overall influences of metals in aquatic systems.

These studies pointed out several considerations important in studying nutritional and pollutant absorption from food by benthic animals. By employing pulse-chase procedures, absorption efficiencies and digestive processing can be assessed in experiments as short as $24 \mathrm{~h}$ for Potamocorbula amurensis and 72 to $96 \mathrm{~h}$ for Macoma balthica. The food concentrations were purposefully kept low to avoid excessive pseudofeces production (Bricelj \& Malouf 1984). Preliminary experiments showed a clear distinction was not achieved between the 2 phases of digestion at high food concentrations. This was probably because intestinal production of feces overlapped with fecal release from the digestive gland when excess food was taken into the stomach. Bacteria-bound ${ }^{51} \mathrm{Cr}$ was not inertly passed through glandular digestion by either species in our experiments. Thus ${ }^{14} \mathrm{C} /{ }^{51} \mathrm{Cr}$ (Calow \& Fletcher 1972, Lopez \& Cheng 1982, Bricelj \& Malouf 1984) could not be employed to calculate overall absorption efficiencies, although it could be employed during intestinal digestion (where $\mathrm{Cr}$ was not absorbed). Inert, radioactively-labeled acrylic beads of a particle size typically ingested by these species were useful in assessing assimilation of food material. For example, the beads aided in the identification of the separate digestion phascs wher fecal pellets were collected at short time intervals. Although limitations would be expected in the use of these inert materials, there was no significant difference between the minimum gut passage time of ${ }^{51} \mathrm{Cr}$ bacterial cells and ${ }^{51} \mathrm{Cr}$-impregnated beads. Also, patterns of egestion were generally similar for the beads and bacteria, even though the beads are considerably larger ( $15 \mu \mathrm{m}$ dia.) than bacteria and of no food value. Gut passage processes indicated by egestion of the beads, therefore, appeared to be representative of those occurring with at least some types of real food material 
Acknowledgements. We thank Drs D. Penry, F. Nichols, and J. Thompson, and anonymous reviewers for helpful suggestions and constructive criticisms on various portions of this manuscript. Mention of brand name products does not constitute an endorsement by the U.S. Geological Survey.

\section{LITERATURE CITED}

Bayne, B. L., Newell, R. C. (1983). Physiological energetics of marine molluscs. In: Wilbur, K. M. (ed.) The Mollusca, Vol. III. Academic Press, New York

Bayne, B. L., Hawkins, A. J. S., Navarro, E., Iglesias, I. P. (1989), Effects of seston concentration on feeding, digestion and growth in the mussel Mytilus edulis. Mar. Ecol. Prog. Ser. 55: 47-54

Birkbeck, T. H. McHenery, J. G. (1982). Degradation of bacteria by Mytilus edulis. Mar. Biol. 72: 70-88

Borchardt, T (1985). Relationships between carbon and cadmium uptake in Mytilus edulis. Mar. Biol. 85: 233-244

Bremer, P. J., Barker, M. F., Loutit, M. W. (1990). A comparison of the roles of direct absorption and phytoplankton ingestion in accumulation of chromium by sea urchin larvae. Mar. environ. Res. 30: 233-241

Bricelj, V. M., Malouf, R. E. (1984). Influence of algal and suspended sediment concentrations on the feeding physiology of the hard clam Mercenaria mercenaria. Mar. Biol. 84: $155-165$

Bricelj, V. M., Bass, A. E., Lopez, G. R. (1984). Absorption and gut passage time of microalgae in a suspension feeder: an evaluation of the ${ }^{51} \mathrm{Cr}:{ }^{14} \mathrm{C}$ twin tracer technique. Mar. Ecol. Prog. Ser. 17: 57-63

Cain, D. J., Luoma, S. N. (1986). Effect of seasonally changing tissue weight on trace metal concentrations in the bivalve Macoma balthica in San Francisco Bay. Mar. Ecol. Prog. Ser. 28: 209-217

Calow, P. (1975). Defaecation strategies of two freshwater gastropods, Ancylus fluviatilis Mull. and Planorbis contortus Linn. (Pulmonata) with a comparison of field and laboratory estimates of food absorption rate. Oecologia (Berl.) 20: 51-63

Calow, P., Fletcher, C. (1972). A new radiotracer technique involving ${ }^{14} \mathrm{C}$ and ${ }^{51} \mathrm{Cr}$ for estimating the assimilation efficiencies of aquatic primary consumers. Oecologia (Berl.) 9: 155-170

Carlton, J T., Thompson, J. K., Schemel, L. E., Nichols, F. H. (1990). Remarkable invasion of San Francisco Bay (California, USA), by the Asian clam Potamocorbula amurensis. I. Introduction and dispersal. Mar. Ecol. Prog. Ser. 66: $81-94$

Hawkins, A. J S., Bayne, B. L., Clark, K. R. (1983). Coordinated rhythms of digestion, absorption and excretion in Mytilus edulis (Bivalvia: Mollusca). Mar. Biol. 74: 41-48

Harvey, R. W., Luoma, S. N. (1985). Effect of adherent bacteria and bacterial extracellular polymers upon assimilation by Macoma balthica of sediment-bound Cd, Zn and Ag. Mar. Ecol. Prog. Ser. 22: 281-289

Hobbie, J. E., Crawford, C. C. (1969). Respiration corrections for bacterial uptake of dissolved organic compounds in natural waters. Limnol. Oceanogr. 14:528-532

Hobbie, J. E., Daley, R. J., Jasper, S. (1977). Use of nuclepore filters for counting bacteria by fluorescence microscopy. Appl. environ. Microbiol. 33: 1225-1228

Johns, C., Luoma, S. N., Elrod, V. (1988). Selenium accumulation in benthic bivalves and fine sediments of San Francisco Bay, the Sacramento-San Joaquin Delta, and selected tributaries. Estuar. coast. Shelf Sci. 27: 381-396 Johns, C., Luoma, S. N. (1990). Arsenic in benthic bivalves of San Francisco Bay and the Sacramento/San Joaquin river delta. Sci. total Environ. 97/98: 673-684

Kofoed, L., Forbes, V., Lopez, G. (1989). Time-dependent absorption in deposit-feeders. In: Lopez, G. R., Taghon, G., Levinton, $J$ (eds) Ecology of marine deposit feeders Lecture Notes on Coastal and Estuarine Studies, Vol. 31 Springer-Verlag, New York, p. 129-148

Lopez, G. R., Cheng, I-J. (1982). Ingestion selectivity of sedimentary organic matter by the deposit-feeder Nucula annulata (Bivalvia: Nuculidae). Mar Ecol. Prog. Ser. 8 $279-282$

Lopez, G. R., Tantichodok, P., Cheng, I-J. (1989). Radiotracer methods for determining utilization of sedimentary organic matter by deposit feeders. In: Lopez, G. R., Taghon, G., Levinton, J. (eds) Ecology of marine depositfeeders. Lecture Notes on Coastal and Estuarine Studies, Vol. 31. Springer-Verlag, New York, p. 149-170

Luoma, S. N. (1983). Bioavailability of trace metals to aquatic organisms - a review. Sci. total Environ. 28: 1-22

Luoma, S. N. (1989). Can we determine the biological availability of sediment-bound trace elements? Hydrobiologia 176/177: 379-396

Luoma, S. N., Cain, D., Johansson, C. (1985). Temporal fluctuations in silver, copper and zinc in the bivalve Macoma balthica at five stations in South San Francisco Bay. Hy. drobiologia 129: 109-120

Luoma, S. N., Johns, C., Fisher, N. S., Steinberg, N. A., Oremland, R. S., Reinfelder, J. (in press) Determination of selenium bioavailability to a benthic bivalve from particulate and solute pathways. Environ. Sci. Technol.

McHenery, J. G., Birkbeck, T H. (1985). Uptake and processing of cultured microorganisms by bivalves. J. Exp. mar. biol. Ecol 90: 145-163

Newell, R. C. (1965). The role of detritus in the nutrition of two marine deposit feeders, the prosobranch Hydrobla ulvae. and the bivalve Macoma balthica. Proc. Zool. Soc., Lond. 144: $25-45$

Nichols, F. H., Thompson, J. K., Schemel, L. E. (1990) Remarkable invasion of San Francisco Bay (California, USA) by the Asian clam Potamocorbula amurensis. If Displacement of a former community. Mar. Ecol. Prog. Ser. 66: $95-101$

Owen, G. (1974). Feeding and digestion in the Bivalvia. Adv. comp. Physiol. Biochem. 5: 1-35

Penry, D. L., Jumars, P. A. (1986). Chemical reactor analysis and optimal. digestion. Bioscience 36: 310-315

Phillips, D. J. H. (1979). Trace metals in the common mussel Mytilus edulis (L.) and in the alga Fucus vesiculosus (L.) from the region of the Sound (Oresund). Environ. Pollut. 18: $31-43$

Purchon, R. D. (1977). The biology of the Mollusca, 2nd edn. Pergamon Press, Oxford

Prieur, D. (1981). Experimental studies of trophic relationships between marine bacteria and bivalve molluscs. Kiel. Meeresforsch. (Sondh.): 5 376-383

Prieur, D., Mevel, G., Nicolas, J. L., Plusquellec, A., Vigneulle, M. (1990). Interactions between bivalve molluscs and bacteria in the marine environment. Oceanogr. mar. biol. A. Rev. 28: 277-352

Reid, R. G. B., Rauchert, K. (1972). Protein digestion in members of the genus Macoma (Mollusca: Bivalvia). Comp. Biochem. Physiol. 41A: 887-895

Riggs, D S. (1963). The mathematical approach to physiological problems, Williams \& Wilkins Co., Baltimore, p. $120-167$ 
Shipley, R. A., Clark, R. E. (1972). Tracer methods for in vivo kinetics. Academic Press, New York

Sokal, R. R., Rohlf, F. J. (1981). Biometry, 2nd edn. W. H. Freeman \& Co., San Francisco

Spacie, A., Hamelink, J. L. (1985). In: Rand, G. M., Pettrocelli, S. R. (eds) Fundamentals of aquatic toxicology. Hemisphere Publ., Washington, D.C., p. 495-525

Steele, R. G. D., Torrie, J. H. (1980). Principle and procedures of statistics, a biometric approach, 2nd edn. McGraw-Hill Co., New York

This article was submitted to the editor
Tunnicliffe, V., Risk, M. J. (1977). Relationships between the bivalve Macoma balthica and bacteria in intertidal sediments: Minas Basin, Bay of Fundy. $J$ mar Res. 35: $499-507$

Widdows, J., Fieth, P., Worrall, C. M. (1979). Relationship between seston, available food and feeding activity in the common mussel Mytilus edulis. Mar. Biol. 50: 195-207

Wilkinson, L. (1987). SYSTAT: the system for statistics. Evanston, III: Systat. Inc.

Manuscript first received: July 18, 1991

Revised version accepted: October 28, 1991 